Commissioned response to Filipe O. Costa \& Gary R. Carvalho, 'The Barcode of Life Initiative: Synopsis and Prospective Societal Impacts of DNA Barcoding of Fish'

\title{
DNA barcoding: potential users
}

\section{PETER M. HOLLINGSWORTH ${ }^{1}$}

The current popularity of DNA barcoding relates to its potential power coupled with its intuitively pleasing simplicity. It is based on the premise of using a standard short region of DNA as a universal tool for identifying organisms. ${ }^{2}$ The aim is to establish a large-scale reference sequence database against which unknown samples can be queried for identification. Where sequences are found that are divergent from others in the database, the corresponding specimens are flagged up as potential new species warranting further investigation. Costa and Carvalho ${ }^{3}$ describe some of the potential societal benefits of DNA barcoding in the context of fish identification and also summarise some of the potential benefits to the discipline of taxonomy itself.

\section{Who will benefit most from DNA based identification?}

Table I lists some examples of people who identify organisms and some of the approaches they may use. Much of the debate around DNA barcoding has focused on its implications for taxonomists and taxonomy. However, if DNA barcoding can be made accessible and cheap, arguably the greatest beneficiaries will be the many professionals whose work involves biological identifications, but whose job is not to carry out taxonomy per se. For this category of people, DNA identification can potentially offer a direct route to the knowledge generated by taxonomists, and avoid them having to spend their time learning how to identify organisms. The opportunities here are immense, given the range of professions that involve biological identifications, and particularly with the growing importance of biodiversity conservation. Of course, there will be limitations. Resource constraints will limit application in some circumstances. A pre-requisite for user confidence is validation of the approach in the taxonomic group of interest, and even a perfectly functioning DNA barcoding system will be dependent on the samples that are fed into it. For example, in field-based surveys targeting the appropriate habitats to sample can require considerable expertise, and the untrained field collector may miss some key species by not knowing where to sample in the first place. Nevertheless, once a sample is available, many professions would benefit from access to automated identification systems (Table I).

The likely use of DNA identification by the broader public is more difficult to quantify. Amateur naturalists are potential beneficiaries in that a cheap and easily accessible DNA identification service could represent a useful training/feedback tool as they are 'getting their eye in' on a given group of organisms. However, given that their enthusiasm is underpinned by an interest in morphological and ecological aspects of biodiversity, there are likely to be limitations as to the extent of uptake and their perceived relevance of DNA barcoding technologies. 
Table I. Some examples of users of taxonomic information and their potential interest in DNA-based identification.

\begin{tabular}{|c|c|c|c|c|c|c|}
\hline & User & Identification need & $\begin{array}{l}\text { Typical source of information for } \\
\text { identification }\end{array}$ & $\begin{array}{l}\text { Identification } \\
\text { skills }\end{array}$ & $\begin{array}{l}\text { Interest in } \\
\text { taxonomy }\end{array}$ & $\begin{array}{l}\text { Potential direct } \\
\text { beneficiary of DNA } \\
\text { identification? }\end{array}$ \\
\hline & Taxonomist & $\begin{array}{l}\text { Assessments of diversity and } \\
\text { distributions }\end{array}$ & $\begin{array}{l}\text { Specialised literature, museum } \\
\text { collections, field guides, databases, } \\
\text { colleagues }\end{array}$ & High & High & $\begin{array}{l}\text { Yes } \\
\text { (for routine identification } \\
\& \text { sub-optimal specimens) }\end{array}$ \\
\hline \multirow{6}{*}{ 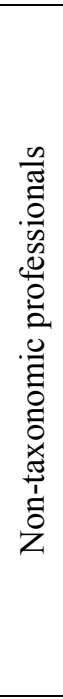 } & Ecologist/life scientist & $\begin{array}{l}\text { Assessments of diversity and } \\
\text { distributions, verification of research } \\
\text { sample identity }\end{array}$ & $\begin{array}{l}\text { Specialised literature, museum } \\
\text { collections, field guides, databases, } \\
\text { taxonomists, colleagues }\end{array}$ & $\begin{array}{l}\text { Variable (low- } \\
\text { high) }\end{array}$ & $\begin{array}{l}\text { Variable (low- } \\
\text { high) }\end{array}$ & Yes \\
\hline & Conservationist & $\begin{array}{l}\text { Assessments of diversity and } \\
\text { distributions, identification of } \\
\text { specimens to conserve }\end{array}$ & $\begin{array}{l}\text { Field guides, images, databases, } \\
\text { taxonomists, colleagues }\end{array}$ & $\begin{array}{l}\text { Variable (low- } \\
\text { high) }\end{array}$ & $\begin{array}{l}\text { Variable (low- } \\
\text { high) }\end{array}$ & Yes \\
\hline & Legal (police, customs) & $\begin{array}{l}\text { Identifications based on fragmentary } \\
\text { material, forensic samples, wildlife } \\
\text { crime/illicit trade }\end{array}$ & $\begin{array}{l}\text { Field guides, images, targeted key, } \\
\text { databases, taxonomists }\end{array}$ & $\begin{array}{l}\text { Variable (low- } \\
\text { high) }\end{array}$ & $\begin{array}{l}\text { Variable (low- } \\
\text { mid) }\end{array}$ & Yes \\
\hline & Human/animal health & $\begin{array}{l}\text { Identification of species with harmful } \\
\text { attributes or medicinal properties }\end{array}$ & $\begin{array}{l}\text { Field guides, images, targeted key, } \\
\text { databases, taxonomists }\end{array}$ & $\begin{array}{l}\text { Variable (low- } \\
\text { high) }\end{array}$ & $\begin{array}{l}\text { Variable (low- } \\
\text { mid) }\end{array}$ & Yes \\
\hline & $\begin{array}{l}\text { Environmental } \\
\text { protection }\end{array}$ & $\begin{array}{l}\text { Identification of indicator species, } \\
\text { identification of invasive/pest species }\end{array}$ & $\begin{array}{l}\text { Field guides, images, targeted key, } \\
\text { databases, taxonomists }\end{array}$ & $\begin{array}{l}\text { Variable (low- } \\
\text { high) }\end{array}$ & $\begin{array}{l}\text { Variable (low- } \\
\text { mid) }\end{array}$ & Yes \\
\hline & $\begin{array}{l}\text { Biodiversity utilisation } \\
\text { (e.g. agriculture, fish } \\
\text { management, forestry, } \\
\text { horticulture) }\end{array}$ & $\begin{array}{l}\text { Identification of species with useful } \\
\text { attributes, identification of species that } \\
\text { impede utilisation (pests/invasives etc) }\end{array}$ & $\begin{array}{l}\text { Field guides, images, targeted key, } \\
\text { databases, specialist colleagues, } \\
\text { taxonomists }\end{array}$ & $\begin{array}{l}\text { Variable (low- } \\
\text { high) }\end{array}$ & $\begin{array}{l}\text { Variable (low- } \\
\text { mid) }\end{array}$ & Yes \\
\hline \multirow{3}{*}{$\frac{0}{3}$} & Amateur naturalist & $\begin{array}{l}\text { Assessments of distributions and } \\
\text { diversity }\end{array}$ & $\begin{array}{l}\text { Specialised literature, museum } \\
\text { collections, field guides, databases, } \\
\text { taxonomists }\end{array}$ & High & High & $\begin{array}{l}\text { Yes } \\
\text { (as a training/feedback } \\
\text { tool) }\end{array}$ \\
\hline & $\begin{array}{l}\text { Passively interested } \\
\text { public }\end{array}$ & Occasional curiosity driven interest & Field guides, images & Low & Low & $\begin{array}{l}\text { Possibly ( may encourage } \\
\text { interest in biodiversity) }\end{array}$ \\
\hline & Uninterested public & - & Nothing & Low & Low & No \\
\hline
\end{tabular}

Genomics, Society and Policy, Vol.3, No.2 (2007) ISSN: 1746-5354

(C) ESRC Genomics Network. 
For the more general public, by improving accessibility to information, there is the potential to generate interest and to instil a greater degree of environmental responsibility. ${ }^{4}$ Costa and Carvalho follow up this point and discuss the potential impacts of easy access to DNA barcoding for the 'ordinary citizen' and note that:
It may trigger a curiosity for living organisms, and improve awareness of biodiversity threats, and the perception of how human actions can have a detrimental impact on rates of species extinctions and ecosystem change. Eventually, a more bio-literate society could produce 'greener' individuals, who are more environmentally- responsible in their daily actions, and willing to undertake pro- active measures to minimize their own impact on the planet's biodiversity.

However, it remains to be seen whether a simple technological solution to identifying organisms will have a major impact on public awareness of biodiversity. Access to a hand-held DNA 'barcorder' might lead to an increased interest in biodiversity, but this may be transient as technological developments in other walks of life compete for attention. In considering how society responds to resources available for identification, it is worth reflecting on situations where a high density of information already exists. In well characterised regions of the world which have comparatively low numbers of species such as the British Isles, there are many easy-to-use illustrated field guides which enable the identification of organisms from a range of taxonomic groups. However, this has not led to comprehensive bioliteracy. ${ }^{5}$ In cases such as this, access to taxonomic information per se is not the limiting factor. Rather it is more likely to be attributable to the level of interest/enthusiasm/need being insufficient to acquire the knowledge, even with the necessary tools at hand. A hand-held DNA 'barcorder' may make identifications and access to associated information easier, but it still requires an inclination for use in the first place. The main drivers for environmental awareness for the general public seem likely to remain day-to-day contact with biodiversity ${ }^{6}$ and exposure to captivating environmental reportage in the mainstream media.

\section{The future use of DNA barcoding}

DNA barcoding represents the key foundation step in the process of coordinating the use of DNA for taxonomy at the species level. ${ }^{7}$ It has already accelerated the routine establishment of 'DNA ready' collections for herbaria and museums. It has triggered a formalisation of links between sequence data and voucher specimens in Genbank, and the development of informatics systems linking specimens, sequences, names and associated information. It has without doubt stimulated biologists using DNA data at the species level to pay much greater attention to coordinating activities and to think beyond producing local solutions for individual studies.

The vision put forward by Herbert et al, ${ }^{8}$ Janzen $^{9}$ and colleagues for DNA barcoding has in turn prompted considerable debate. Several biologists have questioned both the scientific validity of the approach, and its broader implications for the future of taxonomy. ${ }^{10}$ However, given the general benefits that have emerged from the 
coordinated use of genetics in other disciplines and the societal need for biological identifications, it seems difficult to imagine that an appropriately implemented coordinated use of genetics in species level taxonomy can be anything other than beneficial. The exact form of this approach can be expected to evolve as technologies develop, and the future will undoubtedly involve approaches that go beyond single gene sequencing. But as long as there is a demand for the conservation and utilisation of species (eg, Table I), there will be a need for their identification. A system which enables this to be automated has to be worth developing.

\section{Acknowledgements}

I am grateful to Toby Pennington, David Harris, Mark Watson, Michelle Hollingsworth and Rebecca Ellis for helpful discussions on this article.

\footnotetext{
${ }^{1}$ Royal Botanic Garden, Edinburgh, UK P.Hollingsworth@,rbge.org.uk

${ }^{2}$ P.D.N. Hebert et al. Biological identifications through DNA barcodes. Proceedings of the Royal Society of London, series B 2003; 270: 313-321.

${ }^{3}$ F.O. Costa and G.R. Carvalho. The Barcode of Life Initiative: synopsis and prospective societal impacts of DNA barcoding of fish. Genomics, Society and Policy 2007; 3 (2):29-40.

${ }^{4}$ M. Holloway. Democratizing taxonomy. Conservation in Practice 2006; 7: 14-21; D.H. Janzen. Now is the time. Philosophical Transactions of the Royal Society of London, Series B 2004; 359: 731-732.

${ }^{5}$ (c.f. Holloway, op. cit. note 4; Costa and Carvalho, op. cit. note 3.

${ }^{6}$ J.R. Miller. Biodiversity conservation and the extinction of experience. Trends in Ecology and Evolution 2005; 20: 430-434.

${ }^{7}$ Hebert et al, op. cit. note 2 .

${ }^{8}$ Ibid

${ }^{9}$ Janzen, op. cit. note 4.

${ }^{10}$ M.C. Ebach and C. Holdrege. DNA barcoding is no substitute for taxonomy. Nature 2005; 434: 697; Q.D. Wheeler. Losing the plot: DNA "barcodes" and taxonomy. Cladistics 2005; 21: 405-407. K.W. Will, B.D. Mishler and Q.D. Wheeler. The perils of DNA barcoding and the need for integrative taxonomy. Systematic Biology 2005; 54: 844-851.
} 